\title{
A novel manganese complex LMnAc selectively kills cancer cells by induction of ROS-triggered and mitochondrial-mediated cell death
}

\author{
LI Xiang ${ }^{1}$, ZHAO KaiDi $^{1}$, GUO WenJie ${ }^{1}$, LIU Xu ${ }^{1}$, LIU Jia ${ }^{1}$, GAO Jing ${ }^{1 *}$, \\ CHEN QiuYun ${ }^{2} \&$ BAI YiDong ${ }^{3}$ \\ ${ }^{1}$ School of Pharmacy, Jiangsu University, Zhenjiang 212013, China; \\ ${ }^{2}$ School of Chemistry \& Chemical Engineering, Jiangsu University, Zhenjiang 212013, China; \\ ${ }^{3}$ Department of Cellular and Structural Biology, University of Texas Health Science Center at San Antonio, San Antonio, TX 78229, USA
}

Received April 21, 2013; accepted November 8, 2013; published online June 13, 2014

\begin{abstract}
We previously identified a novel synthesized metal compound, $\mathrm{LMnAc}\left(\left[\mathrm{L}_{2} \mathrm{Mn}_{2}(\mathrm{Ac})\left(\mathrm{H}_{2} \mathrm{O}\right)_{2}\right](\mathrm{Ac})\right.$ ( $\mathrm{L}=$ bis $(2$-pyridylmethyl) amino-2-propionic acid)). This compound exhibited significant inhibition on cancer cell proliferation and was more selective against cancer cells than was the popular chemotherapeutic reagent cisplatin. In this study, we further investigated the underlying molecular mechanisms of LMnAc-induced cancer cell death. We found that LMnAc achieved its selectivity against cancer cells through the transferrin-transferrin receptor system, which is highly expressed in tumor cells. LMnAc triggered cancer cells to commit autophagy and apoptosis, which was mediated by the mitochondrial pathway. Moreover, LMnAc disrupted mitochondrial function, resulting in mitochondrial membrane potential collapse and ATP reduction. In addition, LMnAc induced intracellular $\mathrm{Ca}^{2+}$ overload and reactive oxygen species generation. Interestingly, its anticancer effect was significantly reduced following pretreatment with the antioxidant $\mathrm{N}$-acetyl cysteine, indicating that reactive oxygen species triggered cell death. Altogether, our data suggest that LMnAc appears to be a selectively promising anticancer drug candidate.
\end{abstract}

Mn(II) complex, selective, antitumor, autophagy, apoptosis, mitochondria, ROS

Citation: $\quad$ Li X, Zhao KD, Guo WJ, Liu X, Liu J, Gao J, Chen QY, Bai YD. A novel manganese complex LMnAc selectively kills cancer cells by induction of ROS-triggered and mitochondrial-mediated cell death. Sci China Life Sci, 2014, 57: 998-1010, doi: 10.1007/s11427-014-4682-6

Following the landmark discovery of the biological activity of cisplatin [1], metal-based compounds have offered possibilities for the design of therapeutics to study and treat a variety of human diseases. To date, cisplatin remains one of the most effective anticancer drugs in clinical use, while more and more novel metal-based anticancer complexes have been and are being developed [2-5]. In recent years, much research has focused on $\mathrm{Fe}, \mathrm{Ru}, \mathrm{Os}$, and, V. These studies have demonstrated that inducing ROS and cell death is a well-known mechanism of bioinorganic complexes [6].

Of all the metals, manganese $(\mathrm{Mn})$, a required cofactor for many ubiquitous enzymes [7], is an essential trace ele-

*Corresponding author (email: jinggao@ujs.edu.cn) ment that plays a central role in the biochemistry and physiology of many living organisms. Simple Mn(II) salts have been reported to exert anti-proliferative effects on several cancer cell lines generally by induction of apoptotic cell death [8]. Moreover, the transport mechanism of $\mathrm{Mn}$ (II) in vivo may make $\mathrm{Mn}$ (II)-based compounds possible tumor-targets [5,9]. Recently, combining Mn(II) with other functional molecules has become a new strategy for the development of potent anti-tumor compounds. Ligands can significantly alter biological properties by limiting the adverse effects of metal ion overload and facilitate metal ion re-distribution [10]. For example, Mn(II) complexes containing thiosemicarbazone, hydrazone groups or chrysin were reported to have obvious anti-tumor effects $[5,11,12]$. 
$\mathrm{N}$-allyl di(picolyl)amine (L), used as a ligand in this study, has been reported to be both active against the proliferation of cancer cells and capable of complexing Mn(II) [13]. In addition, this compound is highly stable [13].

Of note, cancer is associated with programmed cell death (PCD), which plays a crucial role in the development and homeostasis of multicellular organisms [14]. Apoptosis, type I PCD, targeting malignant cells has always been the aim of anticancer therapies [15]. Most antitumor therapies including chemotherapy primarily act by inducing apoptosis in cancer cells; however, defects in apoptosis programs may cause resistance [16-18]. Autophagy, type II PCD, is distinct from apoptosis [19-21], and is a cellular suicide pathway that operates by digestion of essential cellular proteins [22]. More importantly, some investigations have demonstrated that the co-regulation of both apoptosis and autophagy can participate in mammalian cell death [23]. It has reported that autophagy increases the cytotoxicity of irradiation in apoptosis-deficient cells, demonstrating the ability of autophagy to overcome resistance to apoptosis in cancer cells [24]. Moreover, new insights into the molecular mechanisms of autophagy are now leading to the discovery of exciting new potential drug targets [25]. Other reports have further pointed out that apoptosis and autophagy may be interconnected and even simultaneously regulated by the same trigger such as reactive oxygen species (ROS) and $\mathrm{Ca}^{2+}[26,27]$.

In addition, mitochondria are the primary site of ROS generation within cells and are also sensitive targets for ROS [28]. Several studies have shown that the global shutdown of mitochondrial function under conditions of oxidative stress could contribute to apoptosis [29,30]. During apoptosis, mitochondrial dysfunction is induced, resulting in several patterns of mitochondrial change, including collapse of the mitochondrial transmembrane potential, reduction of intracellular ATP levels and intracellular $\mathrm{Ca}^{2+}$ overload $[29,31]$, which are also involved in autophagy. Furthermore, the fact that mitochondria play a key role in the regulation of cell death pathways makes them an attractive target for cancer chemotherapy [32].

It has been reported previously that newly synthesized $\mathrm{Mn}(\mathrm{II})$ complex LMnAc $\left(\left[\mathrm{L}_{2} \mathrm{Mn}_{2}(\mathrm{Ac})\left(\mathrm{H}_{2} \mathrm{O}\right)_{2}\right](\mathrm{Ac}) \quad(\mathrm{L}=\right.$ bis(2-pyridylmethyl)amino-2-propionic acid)) exhibited good antitumor activity, but the mechanism remains unclear [33]. Therefore, the aim of the present study was to analyze the possible mechanism of LMnAc-induced cell death and its antitumor effect. This was assessed by investigating the relationship between cancer cell death and mitochondrial dysfunction.

\section{Materials and methods}

\subsection{Materials}

Compound LMnAc was synthesized by Professor Chen
QiuYun at Jiangsu University (China). GFP-LC3 plasmid was generously provided by Professor Qin ZhengHong at Soochow University (China). 3-[4,5-dimehyl-2-thiazolyl]2,5-diphenyl-2H-tetrazolium bromide (MTT) was purchased from Amresco (USA). 5,5',6,6'-tetrachloro-1,10, 3,30-tetraethylbenzimidazolylcarbocyani-n-eiodide (JC-1), Fluo-3AM, and lipofectamine 2000 were bought from Invitrogen (USA). Hoechst 33342, 3-MA, CCCP and monodansylcadaverine (MDC) were purchased from SigmaAldrich (USA). Culture medium (DMEM/1640), trypsin and EDTA-2-Na were purchased from Gibco (USA). Fetal bovine serum was obtained from Sijiqing Biological Engineering Materials (China). DCFH-DA, NAC and LysoTracker Red were bought from Beyotime Institute of Biotechnology (China). Antibodies against TfR1, DMT-1, cytochrome c (Cyto C), pro-caspase9, LC3, Beclin-1, and $\beta$-actin were from Abcam (UK). All other chemicals were of high purity from commercial sources.

\subsection{Cell culture}

Four human cancer cell lines-the cervical cancer cell line HeLa, glioma cell line U251, hepatoma cell line HepG2, lung cancer cell line A549 and human liver cell line WRL-68-were obtained from the Cancer Cell Repository (Shanghai Cell Bank). Cells were maintained in RPMI-1640 medium and DMEM medium (Gibco) supplemented with $10 \%(\mathrm{v} / \mathrm{v})$ fetal bovine serum and antibiotics $\left(100 \mathrm{U} \mathrm{mL}^{-1}\right.$ penicillin and $100 \mathrm{U} \mathrm{mL}^{-1}$ streptomycin), and maintained at $37^{\circ} \mathrm{C}$ in a humidified atmosphere of $5 \%(\mathrm{v} / \mathrm{v}) \mathrm{CO}_{2}$.

\subsection{MTT assay to evaluate cell viability and selectivity}

Cell viability was evaluated by means of the MTT assay [34]. Briefly, cells were plated at a density of approximately $4 \times 10^{3}$ viable cells per well in 96-well plates. Various concentrations of the compound were used to treat cells in quintuplicate. After incubation for the indicated time, the MTT assay was performed to measure cell viability using a 96-well plate reader (Spectra MAX 190, Molecular Devices Corporation, USA).

\subsection{Western blot analysis to determine protein levels}

Following incubation with LMnAc, $2 \times 10^{6}$ cells were collected and centrifuged at $1000 \times g$, washed with phosphate buffered saline (PBS), lysed in $100 \mu \mathrm{L}$ precooled lysis buffer containing $0.5 \%(\mathrm{v} / \mathrm{v})$ Triton $\mathrm{X}-100,100 \mathrm{mmol} \mathrm{L}^{-1}$ Tris- $\mathrm{HCl}, 150 \mathrm{mmol} \mathrm{L}^{-1} \mathrm{NaCl}, 0.1 \mathrm{U} \mathrm{mL}^{-1}$ aprotinin for $30 \mathrm{~min}$ on ice and centrifuged at $12000 \times \mathrm{g}$ for $2 \mathrm{~min}$. The supernatant was collected followed by protein concentration determination using the NJJC protein assay kit with bovine serum albumin (BSA) as a standard control. Samples were 
mixed with a double volume of sample buffer $\left(62.5 \mathrm{mmol} \mathrm{L}^{-1}\right.$ Tris, pH 6.8, 2\% (w/v) SDS, 5\% (v/v) mercaptoethanol, $1 \%$ $(\mathrm{w} / \mathrm{v})$ bromophenol blue, and $25 \%(\mathrm{v} / \mathrm{v})$ glycerol) and boiled for $5 \mathrm{~min}$. Twenty micrograms of protein was electrophoresed on a $10 \%$ (w/v) SDS-polyacrylamide gel. Protein was transferred to a polyvinylidene-difluoride (PVDF) membrane (Bio-Rad, USA), blocked with 5\% (w/v) skim milk, and incubated overnight at $4^{\circ} \mathrm{C}$ with TfR-1 (1:500), DMT-1 (1:500), pro-caspase9 (1:500), LC3 (1:2000), Beclin-1 (1:1500) and $\beta$-actin (1:2000) primary antibodies diluted in PBS+Tween 20 (PBST). After being washed with PBST, the membrane was incubated in the appropriate HRP-conjugated secondary antibody (diluted 1:2000 in PBST) at room temperature for $2 \mathrm{~h}$, and incubated with enhanced chemiluminescence reagent (ECL) solution for 3 min and visualized.

The mitochondrial proteins were isolated as follows. Aliquots of $2 \times 10^{5}$ A549 cells were seeded onto six-well plates, and harvested following exposure to LMnAc at different time points. Lysates were centrifuged at $12000 \times g$ at $4{ }^{\circ} \mathrm{C}$ for $15 \mathrm{~min}$ to obtain the supernatants (cytosolic extracts free of mitochondria) and the pellets (fraction that contains mitochondria). The pellets were subjected to Western blotting as above. Membranes were incubated overnight at $4{ }^{\circ} \mathrm{C}$ with Cyto C (1:500).

\subsection{MTT assay to analyze the effect of Fe on the inhi- bition of LMnAc}

A549 cells were plated at a density of approximately $4 \times 10^{3}$ viable cells per well in 96-well plates. Cells were pretreated with $10 \mu \mathrm{mol} \mathrm{L}{ }^{-1}$ DFO (deferoxamine) and $100 \mu \mathrm{mol} \mathrm{L}{ }^{-1}$ ferric citrate. Various concentrations $\left(3-15 \mu \mathrm{mol} \mathrm{L}{ }^{-1}\right)$ of LMnAc were used to treat cells in quintuplicate. After incubation for various times, the MTT assay was performed.

\subsection{Morphology of cells}

$\mathrm{H}_{2} \mathrm{~B}$-labeled HeLa cells (stable cell line) were generously provided by Professor Li ChaoJun at Nanjing University (China). The morphological changes of $\mathrm{H}_{2} \mathrm{~B}-\mathrm{GFP}-$ labled HeLa cells were observed under the Nikon Ti-E microscope using the live cell station (LCS), which can supply $\mathrm{CO}_{2}$, maintain temperature and a fixed position. The $\mathrm{H} 2 \mathrm{~B}-$ GFP-labled HeLa cells with $10 \mu \mathrm{mol} \mathrm{L}{ }^{-1}$ LMnAc were observed for $24 \mathrm{~h}$. Bright field and fluorescence images of cells were recorded and analyzed.

\subsection{Hoechst 33342 staining to observe apoptotic nuclei}

A549 cells were treated with LMnAc and the nuclei were stained with Hoechst 33342 [35]. Morphological changes were analyzed under a fluorescence microscope.

\subsection{AnnexinV/PI staining to measure the rate of apop- tosis}

Briefly, following treatment with LMnAc for 0-36 h, A549 cells $\left(1 \times 10^{6}\right)$ were harvested and washed twice with ice-cold PBS. Phosphatidylserine exposed on the outside of apoptotic cells was determined using the Annexin V-FITC apoptosis kit (Molecular Probes, USA). A $5 \mu \mathrm{L}$ aliquot of Annexin V-FITC and $10 \mu \mathrm{L}$ Propyl iodide (PI) buffer were added to $100 \mu \mathrm{L}$ of $1 \times$ Annexin V-FITC binding buffer; cells were then incubated at room temperature for $15 \mathrm{~min}$ in the dark. After adding $400 \mu \mathrm{L}$ of $1 \times$ AnnexinV-FITC binding buffer, the cells were analyzed by flow cytometry (Becton Dickinson FACSCalibur, USA).

\subsection{MDC staining to detect acidic vesicular organelles}

As a marker of autophagy, the volume of the cellular acidic compartment was visualized by MDC staining, as described previously [36]. A549 cells $\left(2 \times 10^{4}\right)$ were seeded onto 24 -well plates and cultured for $24 \mathrm{~h}$. After pretreatment with LMnAc for $24 \mathrm{~h}$, cells were incubated with $50 \mathrm{mmol} \mathrm{L}^{-1}$ $\mathrm{MDC}$ at $37^{\circ} \mathrm{C}$ for $15 \mathrm{~min}$, washed with PBS and then observed under a fluorescence microscope.

\subsection{Lyso-Tracker Red staining to evaluate the activity of lysosomes}

A549 cells treated with $\mathrm{LMnAc}$ for $24 \mathrm{~h}$ were incubated with $50 \mathrm{nmol} \mathrm{L}{ }^{-1}$ Lyso-Tracker Red at $37^{\circ} \mathrm{C}$ for $30 \mathrm{~min}$, washed with PBS and then observed with a fluorescence microscope.

\subsection{GFP-LC3 plasmid transfection to examine LC3 protein aggregation}

A549 cells were transfected with $1 \mu \mathrm{g}$ of GFP-LC3 expressing plasmid in each well of a 24-well plate using lipofectamine 2000. After $4 \mathrm{~h}$, cells were treated with LMnAc, and the fluorescence of GFP or GFP-LC3 was viewed under a fluorescence microscope.

\subsection{JC-1 staining to measure mitochondrial mem- brane potential (MMP)}

MMP was determined using the fluorescent dye JC-1 [37]. A549 cells were seeded in 96-well plates or on chamber slides and treated with LMnAc at the indicated concentrations and times. Fluorescence intensity was measured immediately following $\mathrm{JC}-1$ staining $\left(5 \mathrm{mg} \mathrm{mL}^{-1}\right.$ of $\mathrm{JC}-1$ at $37^{\circ} \mathrm{C}$ for $30 \mathrm{~min}$ ) by fluorescence spectrometry (Molecular Devices Corporation, USA) or observed using a fluorescence microscope (excitation $488 \mathrm{~nm} /$ emission $535 \mathrm{~nm}$ for $\mathrm{JC}-1$ green and excitation $488 \mathrm{~nm} / \mathrm{emission} 595 \mathrm{~nm}$ for JC-1 red). 


\subsection{Luciferase assay to determine intracellular ATP content}

The ATP content was determined by the luciferin-luciferase method [38]. Cells were harvested following different treatments and assayed for ATP using the Beyotime chemical luciferase ATP assay kit.

\subsection{Fluo-3-AM staining to elevate intracellular free $\mathrm{Ca}^{2+}$ concentrations $\left(\left[\mathrm{Ca}^{2+}\right]_{\mathrm{i}}\right)$}

$\left[\mathrm{Ca}^{2+}\right]_{\mathrm{i}}$ was determined using the fluorescent dye Fluo-3-AM [39]. A549 cells treated with LMnAc, were loaded with $3 \mu \mathrm{g} \mathrm{mL} \mathrm{m}^{-1}$ Fluo-3-AM at $37^{\circ} \mathrm{C}$ for $30 \mathrm{~min}$, washed with PBS and the fluorescence of $\left[\mathrm{Ca}^{2+}\right]_{i}$ was viewed under a fluorescence microscope and analyzed by flow cytometry.

\subsection{DCFH-DA staining to detect intracellular ROS}

ROS were measured with the non-fluorescent probe DCFH-DA. DCFH-DA can passively diffuse into cells and be deacetylated by esterase to form non-fluorescent 2,7-dichlorofluorescein (DCFH). In the presence of ROS, $\mathrm{DCFH}$ reacts with ROS to form the fluorescent product DCF which is trapped inside the cells. Analysis of ROS production was performed according to a reported method [40]. Briefly, A549 cells treated with LMnAc were washed with ice-cold PBS and incubated with $10 \mu \mathrm{mol} \mathrm{\textrm {L } ^ { - 1 }}$ DCFH-DA at $37^{\circ} \mathrm{C}$ for $20 \mathrm{~min}$. DCF fluorescence intensity was detected by fluorescence spectrometry (Spectra MAX
GEMINI, Molecular Devices, USA) or observed by fluorescence microscopy (excitation $488 \mathrm{~nm} / \mathrm{emission}$ $535 \mathrm{~nm})$.

\subsection{Statistical analysis}

Differences among all groups were analyzed by one-way ANOVA, followed by the SNK- $q$-test using SPSS 10 software. A $P$-value $<0.05$ was considered statistically significant.

\section{Results}

\subsection{LMnAc-induced selective inhibition in cancer cell viability}

LMnAc exerted good antitumor activity, with values of IC50 for the four cancer cell lines ranging from 8 to 36 $\mu \mathrm{mol} \mathrm{L}{ }^{-1}$ (Table 1). Cells were treated with different (3-15 $\mu \mathrm{mol} \mathrm{L}{ }^{-1}$ ) doses of the complex for $24,36,48 \mathrm{~h}$, and it was found that the inhibition of A549 cell proliferation was not only dose-dependent, but also time-dependent (Figure 1A), which was confirmed by morphological observations (Figure 1B) showing cell body shrinkage and cell number reduction at $24 \mathrm{~h}$ after exposure to 10 or $100 \mu \mathrm{mol} \mathrm{L} \mathrm{L}^{-1}$ LMnAc.

To test the selectivity of LMnAc, the liver cancer cells (HepG2) and the non-malignant liver epithelial cells (WRL-68) were used. LMnAc showed significant selectivity towards HepG2 over WRL-68 (Figure 2A) when compared with cisplatin (Figure $2 \mathrm{~B}$ ). The preferential toxicities
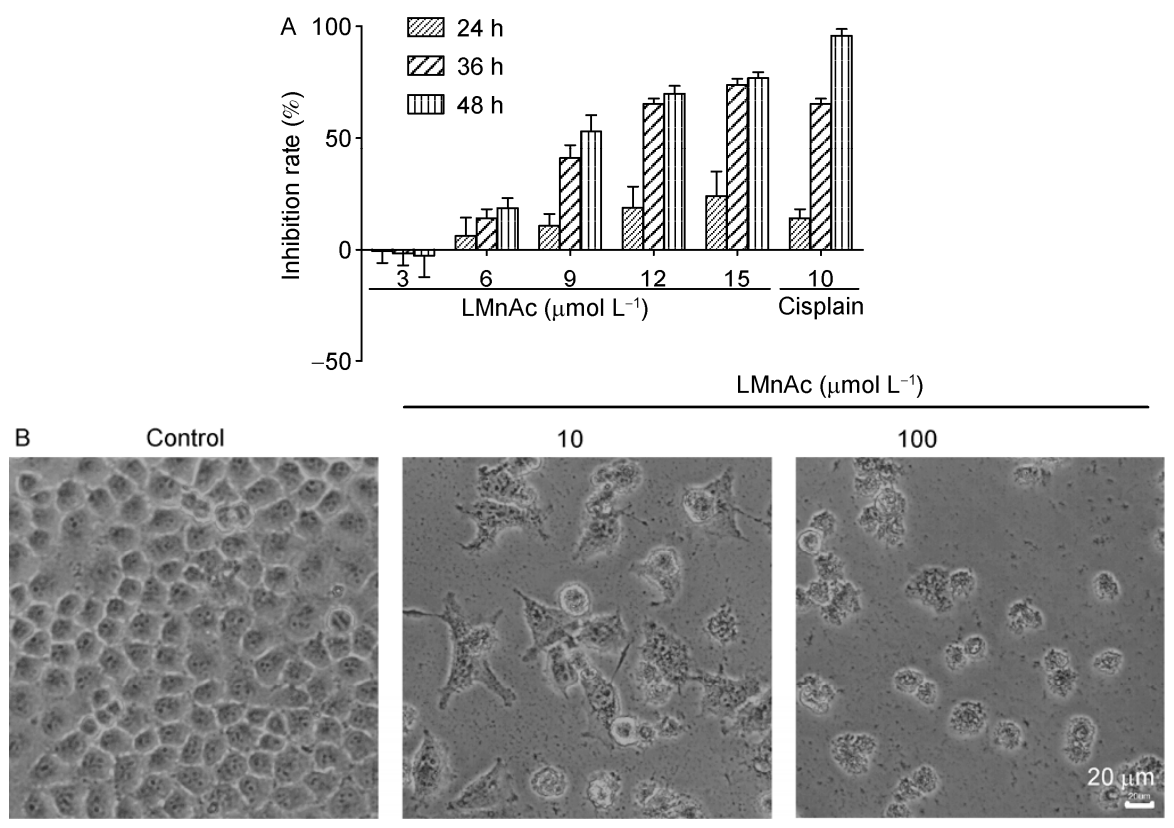

Figure 1 Dose- and time-dependent effect of LMnAc on cell proliferation of A549 cells. A, A549 cells were exposed to LMnAc (3-15 $\mu$ mol $\mathrm{L}^{-1}$ ) or cisplain $\left(10 \mu \mathrm{mol} \mathrm{L}{ }^{-1}\right)$. Each column represents the mean of the data from five independent experiments $(\bar{x} \pm \mathrm{SD}, N=5$, $* P<0.05$ vs. control). B, Morphological changes were induced by LMnAc in A549 cells for $48 \mathrm{~h}$ and observed. 
Table $1 I C_{50}$ values of LMnAc on HeLa, U251, A549 and HepG2 cells for $48 h^{\text {a) }}$

\begin{tabular}{cc}
\hline Cancer cells & $I C_{50}\left(\mu \mathrm{mol} \mathrm{L}^{-1}\right)$ \\
\hline HeLa & $23.1 \pm 1.5$ \\
U251 & $35.8 \pm 0.6$ \\
A549 & $7.9 \pm 0.4$ \\
HepG2 & $29.2 \pm 1.2$ \\
\hline
\end{tabular}

a) Data represent the mean $\pm \mathrm{SD}$ of three independent experiments. $I C_{50}$ values were determined graphically from the growth inhibition curves obtained after a $48 \mathrm{~h}$ exposure of cells to LMnAc, using the software from the China Pharmaceutical University.

towards cancer cells over non-cancer cells suggest strong potential of this compound towards an antitumor application.

\subsection{LMnAc is transported into cells through the Tf-TfR system}

Because of the high expression of TfR and DMT on tumor

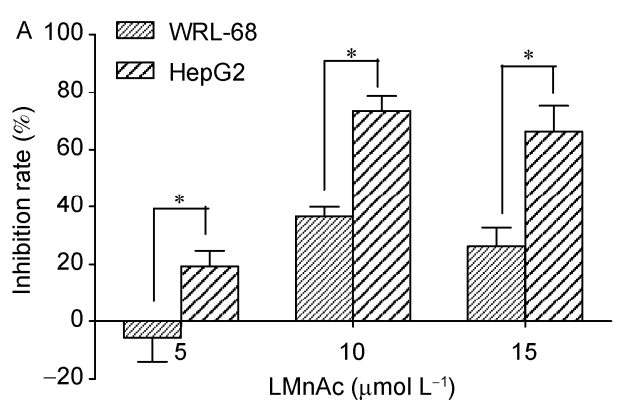

cells, the selectivity of LMnAc may be due to its transport mechanism. We can see from Figure 3A that TfR1 expression in HepG2 cells was higher than WRL-68 cells, while DMT1 levels were almost equal. In addition, as shown in Figure $3 \mathrm{~B}$ and $\mathrm{C}$, ferric citrate pretreatment can reduce TfR1 levels and inhibit the effect of LMnAc on A549 cells, while DFO can promote it (Figure 3B and D).

\subsection{LMnAc induces cell cycle arrest and apoptosis through the mitochondrial pathway}

As indicated in Figure 4A, untreated $\mathrm{H}_{2} \mathrm{~B}$-labeled HeLa cells were shown in an active dividing state suggesting that many of the cells were at metaphase. However, after incubation with $10 \mu \mathrm{mol} \mathrm{L}{ }^{-1} \mathrm{LMnAc}$ for $12 \mathrm{~h}$, the cells shrank, chromatin condensation occurred (Figure 4B) and the features of metaphase nuclei decreased drastically compared with untreated $\mathrm{H}_{2} \mathrm{~B}$-labeled HeLa cells (Figure 4C). With time, the nuclei became condensed and divided into several

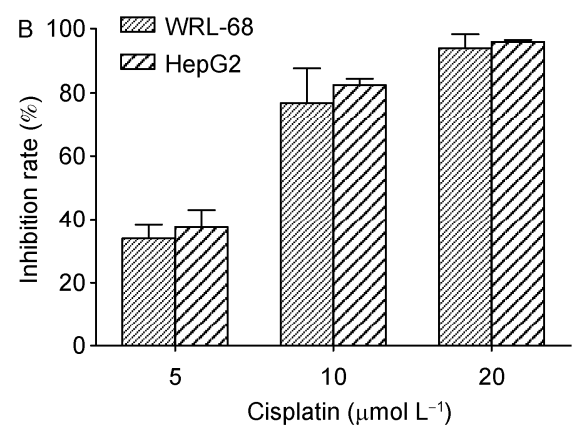

Figure 2 LMnAc exhibited selective inhibition on cancer cell proliferation. HepG2 cells and WRL-68 cells were treated with different concentrations of LMnAC (A) or cisplain (B) for $48 \mathrm{~h}\left(\bar{x} \pm \mathrm{SD}, N=5,{ }^{*}, P<0.05\right)$.
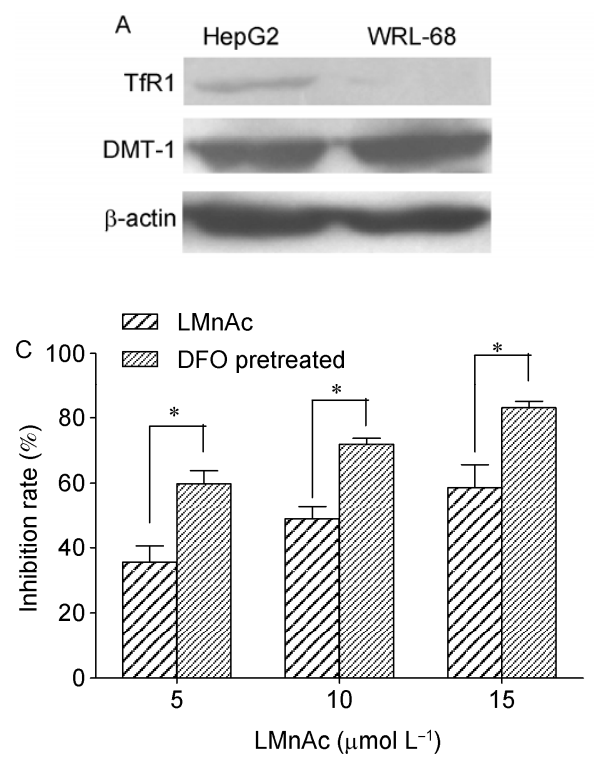
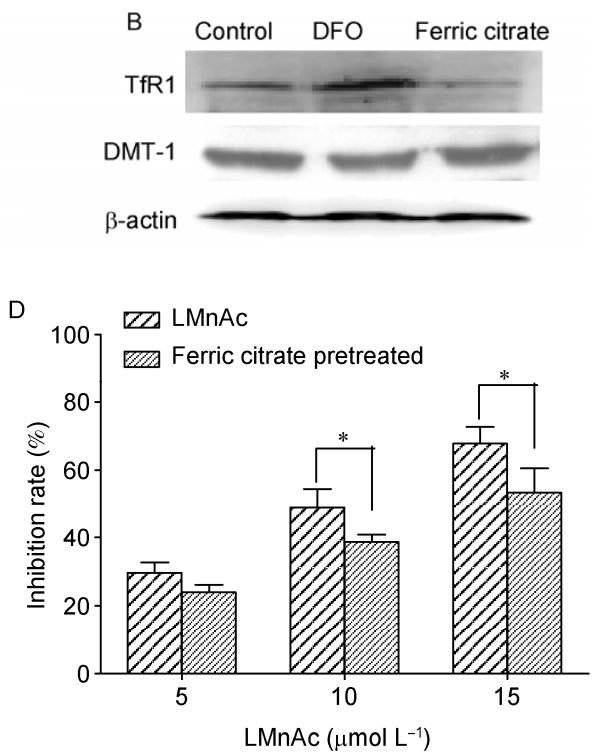

Figure 3 LMnAc was transported into cancer cells through the transferrin-transferrin receptor system. A, Expression of TfR-1 and DMT-1 in HepG2 and WRL-68 cells. B, DFO/ferric citrate promoted/decreased the expression of TfR-1. Cells were pretreated with DFO (10 $\mu$ mol L $\left.\mathrm{L}^{-1}\right)(\mathrm{C})$ or ferric citrate (100 $\left.\mu \mathrm{mol} \mathrm{L} \mathrm{L}^{-1}\right)(\mathrm{D})$ for $24 \mathrm{~h}$, then treated with different concentrations of LMnAc for $24 \mathrm{~h}(\bar{x} \pm \mathrm{SD}, N=5, *, P<0.05 \mathrm{vs}$. control). 
parts coupled with the emergence of apoptotic bodies. The percentage of cells that showed apoptotic nuclei increased in a time-dependent manner (Figure 4D).

The A549 cells stained with Hoechst 33342 exhibited similar microscopic results (Figure 5A, indicated by arrows). To further confirm the ratio of apoptosis, cells treated with LMnAc were analyzed by FACS using Annexin V/PI staining. As shown in Figure $5 \mathrm{~B}$ and $\mathrm{C}$, the apoptotic cells were
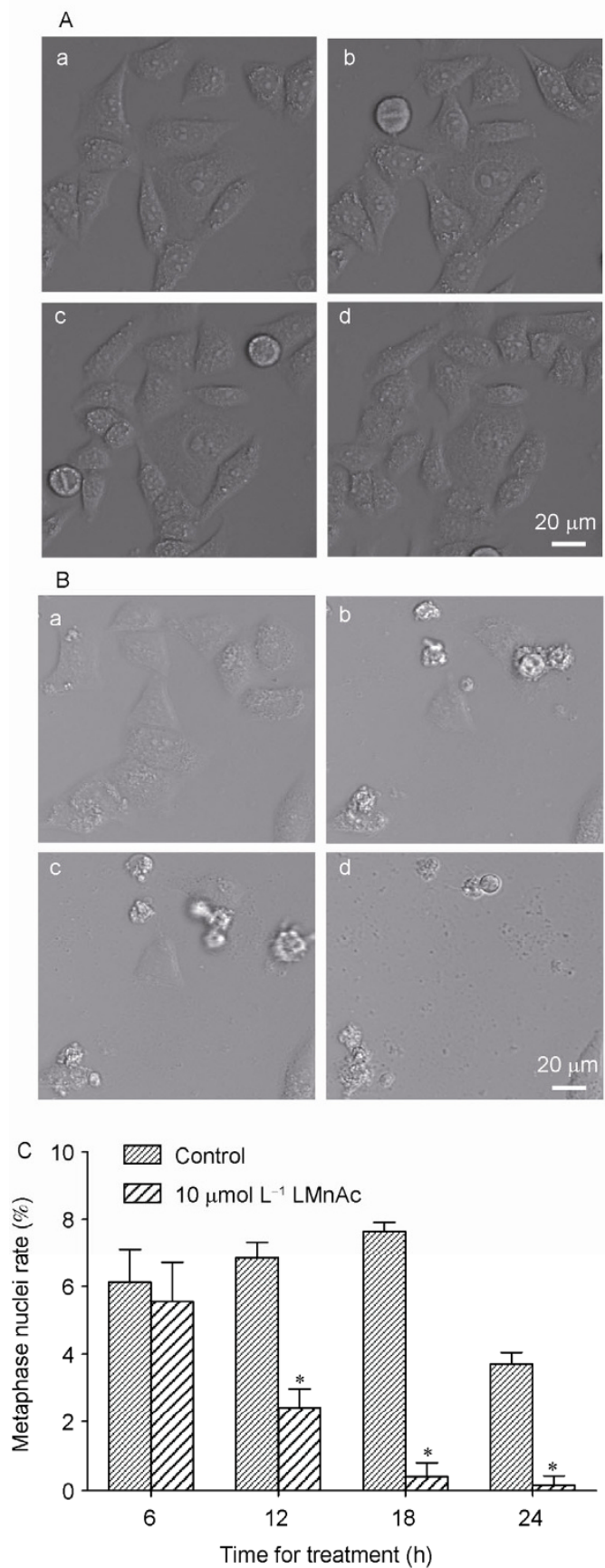

significantly increased following a $36 \mathrm{~h}$ treatment $(47.2 \%$, lower right).

To further examine the pathway of apoptosis, Cyto $\mathrm{C}$ content in the cytosol, a marker of mitochondrial-mediated apoptosis, was examined by Western blot analysis. As shown in Figure 5D and E, both Cyto $\mathrm{C}$ in mitochondria and pro-caspase 9 in the cytosol decreased after being exposed to LMnAC for $12 \mathrm{~h}$, indicating that LMnAc-induced apoptosis
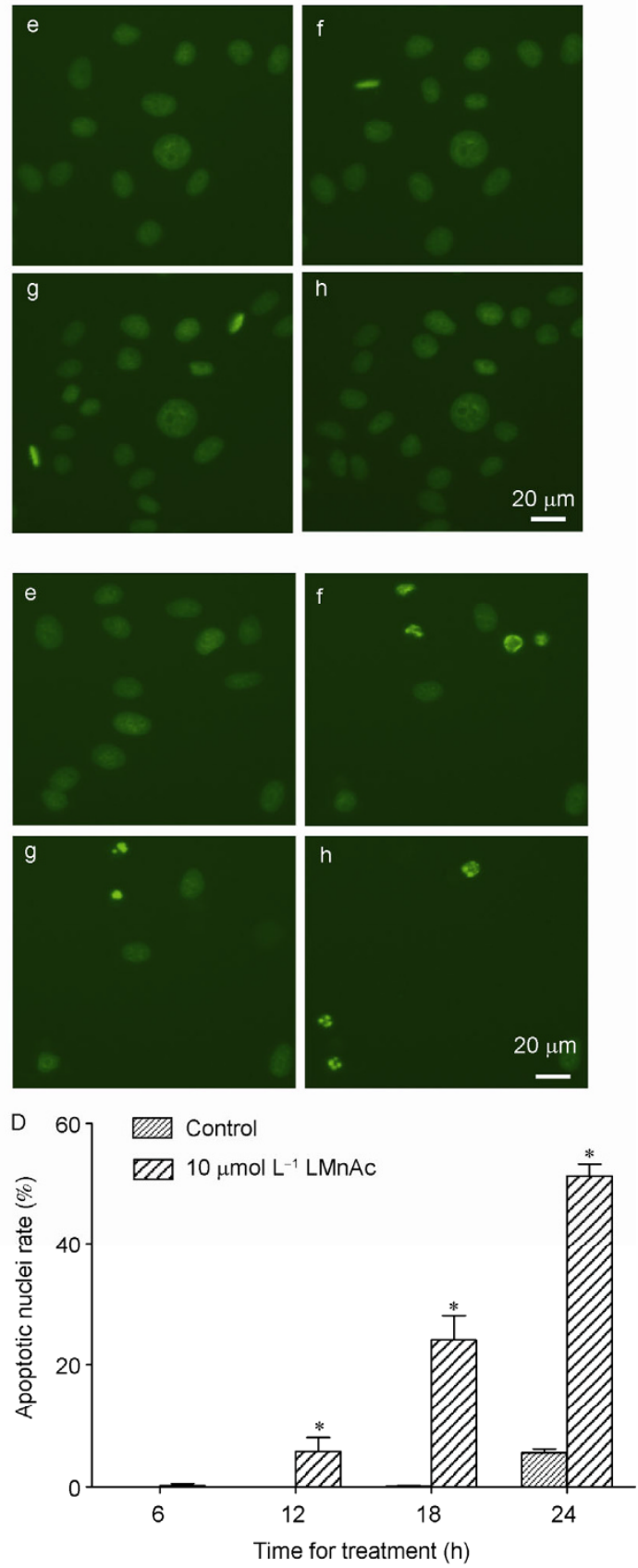

Figure 4 (color online) LMnAc induced apoptosis in $\mathrm{H}_{2} \mathrm{~B}$-labled HeLa cells. Morphological changes of cells and nuclei using the live cell system (LCS) were observed after cells were exposed to $20 \mu \mathrm{mol} \mathrm{L}{ }^{-1}$ of LMnAc. This process lasted for over $24 \mathrm{~h}$. Cells that exhibited reduced nuclear size, appeared shrunken, had intense fluorescence, nuclei fragmentation were apoptotic. A, Control. B, $20 \mu \mathrm{mol} \mathrm{L}{ }^{-1} \mathrm{LMnAc}$. a and e: 6 h; b and f: 12 h; c and g: 18 h; $\mathrm{d}$ and h: 24 h. a-d: bright field images; e-f: fluorescence images of nuclei. Metaphase (C) and apoptotic (D) nuclei were counted from three fields of view at each time point and the percent was calculated ( $\bar{x} \pm \mathrm{SD}, N=3$, ${ }^{*}, P<0.05$ vs. control). 

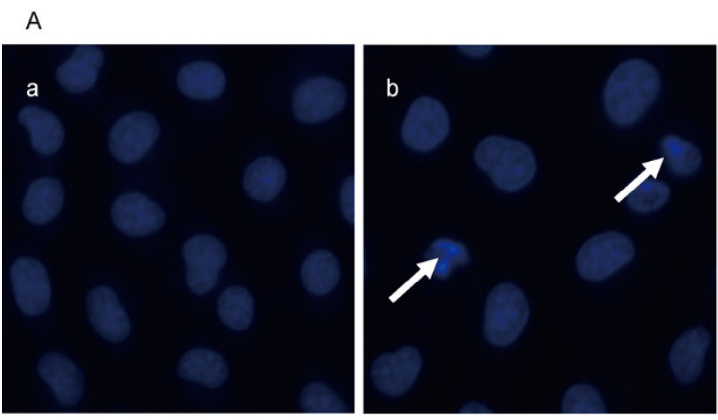

\section{B}
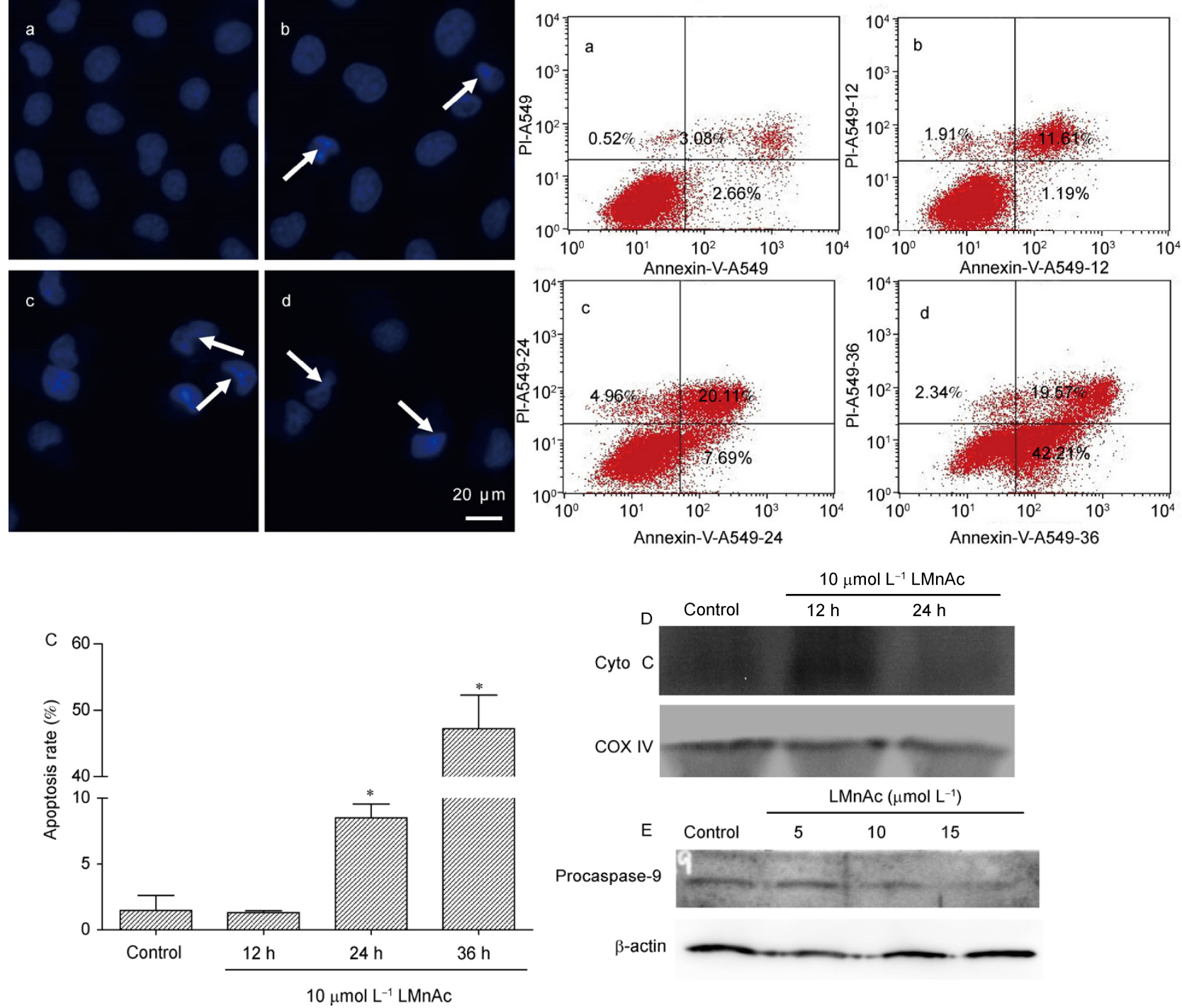

Figure 5 (color online) LMnAc induced apoptosis in A549 cells via the mitochondrial pathway. A, The cells were treated with 5,10 , and $15 \mu$ mol $\mathrm{L}^{-1}$ LMnAc for $24 \mathrm{~h}$, stained with Hoechst 33342, and then images of morphology and nuclei were captured with a Nikon Ti-E PFS microscope. a: control; b: 5 $\mu \mathrm{mol} \mathrm{L}{ }^{-1}$; c: $10 \mu \mathrm{mol} \mathrm{L}{ }^{-1}$; d: $15 \mu \mathrm{mol} \mathrm{L}{ }^{-1}$. B, A549 cells were treated with $10 \mu \mathrm{mol} \mathrm{L} \mathrm{L}^{-1} \mathrm{LMnAc}$ at different time points. The cells were then stained with Annexin V-FITC and propidium iodide in the dark and analyzed by flow cytometry. a: control; b: $12 \mathrm{~h}$; c: $24 \mathrm{~h}$; d: $36 \mathrm{~h}$. C, Apoptosis rates were calculated using three independent experiments ( $\bar{x} \pm \mathrm{SD}, N=3,{ }^{*}, P<0.05$ vs. control). D, CytoC release from mitochondria. E, Pro-casepase 9 levels decreased.

through the mitochondrial pathway.

\subsection{LMnAc-induced autophagic cell death}

In A549 cells, the LMnAc-treated groups showed greater fluorescence intensity and much more MDC-labeled particles than the control group (Figure 6A), indicating that LMnAc increased MDC recruitment to autophagosomes in the cytoplasm. Similarly, the activity of lysosomes was also enhanced in LMnAc-treated groups as compared to the control group (Figure 6B), which occurs normally in autophagy.

Because LC3 is a specific marker for autophagosome formation [41], GFP-LC3 plasmids were transfected into
A549 cells and cells with GFP-LC3 vacuoles (dots) were observed using a fluorescence microscope. In Figure 6C, formation of GFP-LC3 vacuoles (dots) in A549 cells was viewed after treatment with $5-15 \mu \mathrm{mol} \mathrm{L}{ }^{-1} \mathrm{LMnAc}$ for $24 \mathrm{~h}$. Consistent with the results of MDC staining and GFP-LC3 vacuole formation, elevated Beclin-1 and conversion of LC3-I to LC3-II after treatment were also detected (Figure $6 \mathrm{D})$. Furthermore, it was found that after pretreatment with 3-MA, an inhibitor of autophagy, cell death was reduced in a dose-dependent manner (Figure 6E). This indicated that autophagy may be the main cell death pathway involved following 5-10 $\mu \mathrm{mol} \mathrm{L}{ }^{-1} \mathrm{LMnAc}$ incubation for $24 \mathrm{~h}$ in A549 cells. 

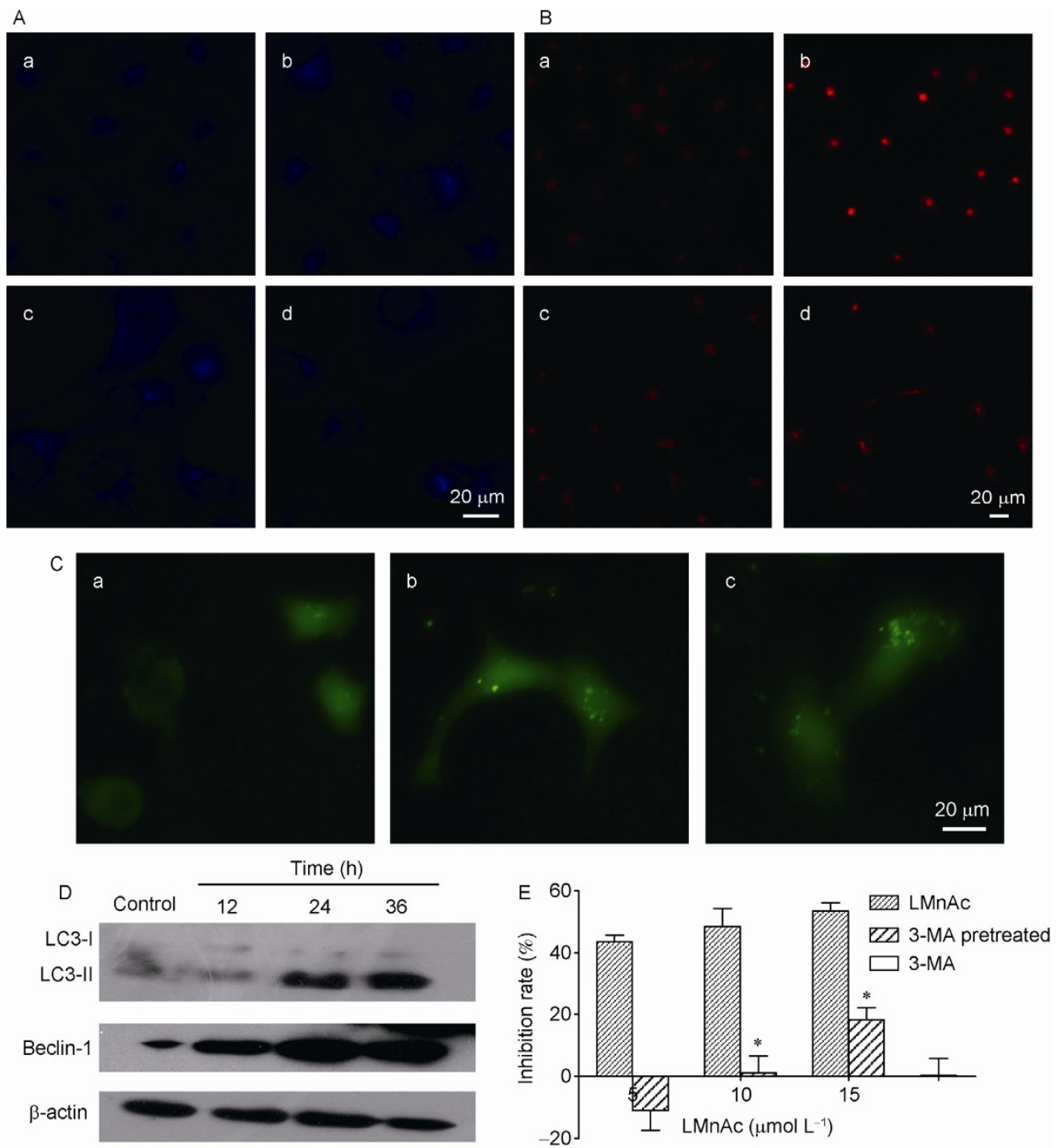

Figure 6 (color online) LMnAc induced autophagy in A549 cells. MDC fluorescence (A), lysosome activity (B) enhanced and induced GFP-LC3 vacuole (dots) formation (C) after treatment with 5, 10 and $15 \mu$ mol L LMnAc. a: control; b: $5 \mu \mathrm{mol} \mathrm{L}{ }^{-1}$; c: $10 \mu$ mol L ${ }^{-1}$; : $15 \mu$ mol L ${ }^{-1}$. Beclin-1 expressions, LC3 expression and conversion of LC3-I to LC3-II were analyzed by Western blotting after treatment with $10 \mu$ mol $\mathrm{L}^{-1} \mathrm{LMnAc}$ for 12 , 24 and $36 \mathrm{~h}$ (D). 3-MA pretreatment reduced cell death and autophagy induced by LMnAc. Cells were pretreated with 3-MA $\left(10 \mathrm{mmol} \mathrm{L}^{-1}\right)$ for $2 \mathrm{~h}$, then treated with LMnAc for $24 \mathrm{~h}$. The MTT assay was used to evaluate cell viability (E) $(\bar{x} \pm \mathrm{SD}, N=5, *, P<0.05$ vs. control).

\subsection{LMnAc-induced mitochondrial dysfunction: de- creased MMP and intracellular ATP levels}

To examine whether the compound affected mitochondrial function, MMP was examined by observing the relative ratio in red and green fluorescence of JC-1. Data of fluorescence spectrometry revealed that the ratio between red and green fluorescence intensity was decreased in the 36-h and 48-h groups, indicating that exposure to the compound for more than $36 \mathrm{~h}$ resulted in depolarization of the mitochondrial membrane (Figure 7A). Treatment with 5, 10, and $15 \mu \mathrm{mol} \mathrm{L} \mathrm{L}^{-1} \mathrm{LMnAc}$ for $48 \mathrm{~h}$ led to MMP collapse, showing enhanced green intensity and reduced red intensity of JC-1 (Figure 7B). However, MMP increased after 5-10 $\mu \mathrm{mol} \mathrm{L}^{-1}$ LMnAc incubation for $24 \mathrm{~h}$, which may be a result of stress.
MMP is the driving force for ATP synthesis. Loss of MMP is expected to cause decreases in ATP levels in cells. The cellar ATP level is an important determinant for cell death. To evaluate whether mitochondrial dysfunction was involved, levels of cellular ATP were determined after LMnAc treatment. As shown in Figure 8, LMnAc induced a time-dependent decrease in cellular ATP levels. Treatment with $10 \mu \mathrm{mol} \mathrm{L}{ }^{-1} \mathrm{LMnAc}$ for $24 \mathrm{~h}$ showed significant ATP depletion compared with the control group, which resulted in a decrease from 1.88 to $1.44 \mathrm{nmol}$ per $\mathrm{mg}$ protein.

\subsection{LMnAc-induced intracellular $\mathrm{Ca}^{2+}$ overload}

Calcium is a key regulator of mitochondrial function and acts at several levels within the organelle, such as stimulat- 

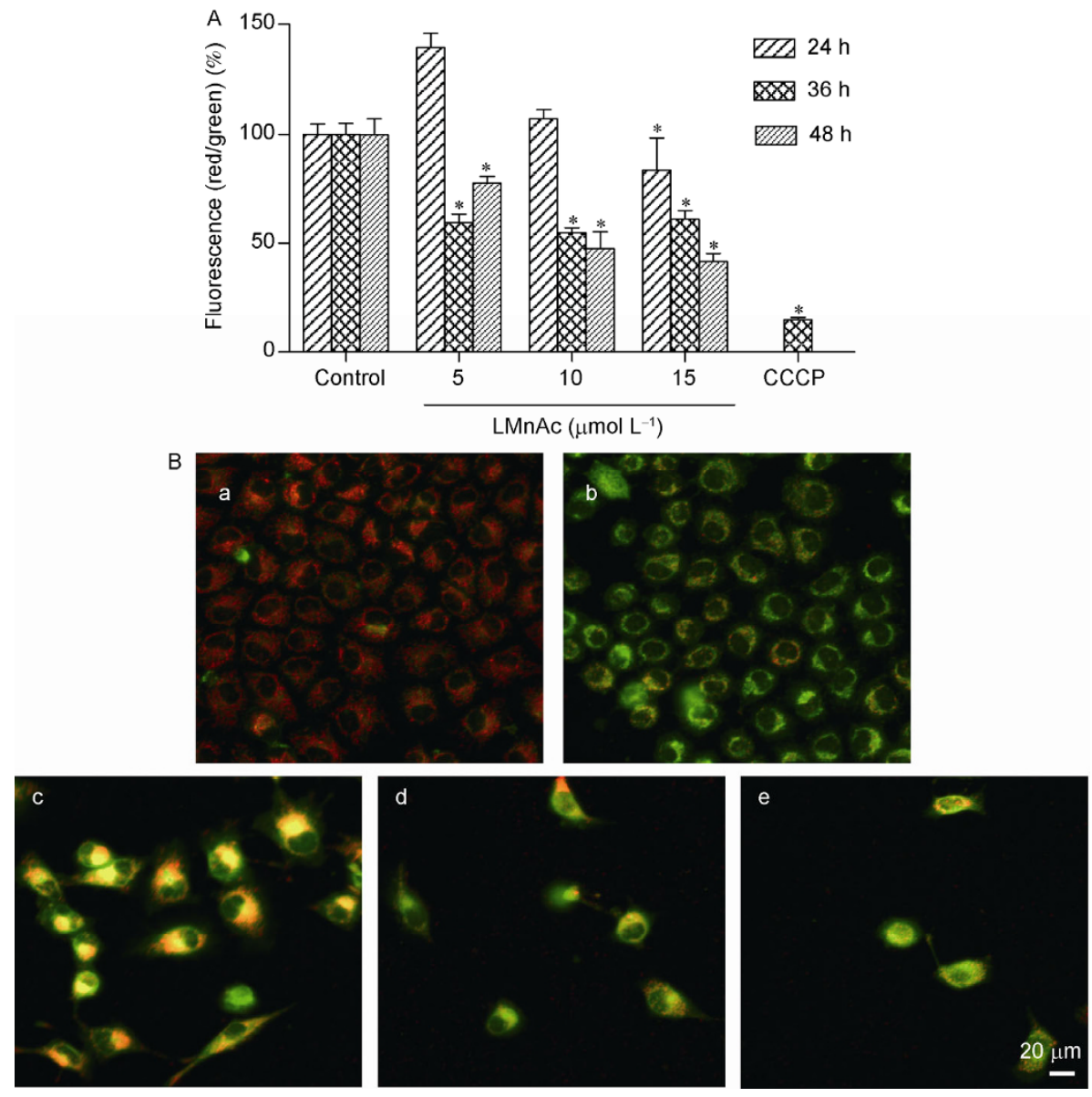

Figure 7 LMnAc induced MMP collapse in A549 cells. A, Dose and time-dependent decrease of red/green fluorescence ratio of JC-1 after treatment with

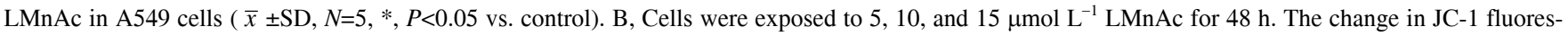
cence in mitochondria was visualized using the Nikon fluorescence microscope. a: control; b: CCCP; c: $5 \mu \mathrm{mol} \mathrm{L}{ }^{-1}$; d: $10 \mu \mathrm{mol} \mathrm{L}{ }^{-1}$; e: $15 \mu \mathrm{mol} \mathrm{L}$.

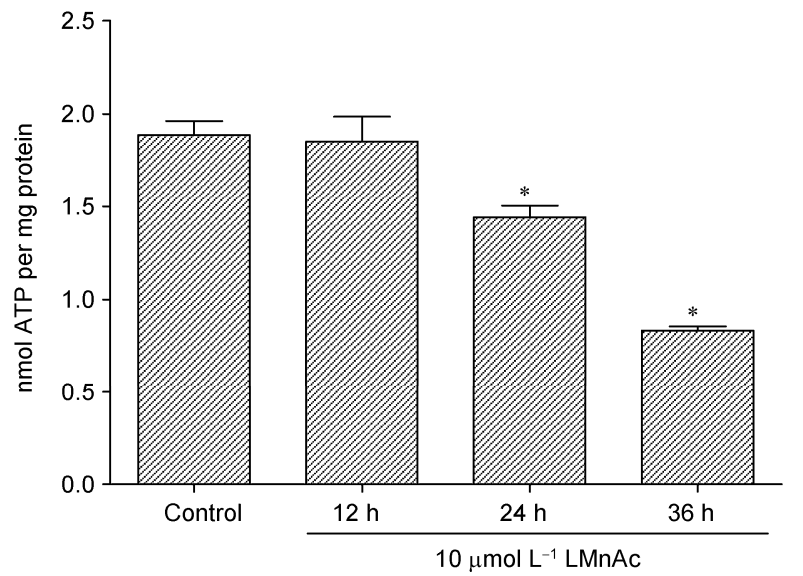

Figure 8 LMnAc decreased intracellular ATP levels. Time-dependent depletion of intracellular ATP following treatment with $10 \mu \mathrm{mol} \mathrm{L}^{-1}$ LMnAc in A549 cells at 12, 24, and $36 \mathrm{~h}$. ATP levels were measured with the luciferin-luciferase assay ( $\bar{x} \pm \mathrm{SD}, N=3, *, P<0.05$ vs. control).

ing ATP synthesis. The $\left[\mathrm{Ca}^{2+}\right]_{\mathrm{i}}$ was determined using the fluorescent dye Fluo-3-AM. The LMnAc-treated groups
(5-15 $\mu \mathrm{mol} \mathrm{L} \mathrm{L}^{-1}$ ) showed higher fluorescence intensity in A549 cells compared with the control group (Figure 9A), with the relative intensity increasing only after $10 \mu \mathrm{mol} \mathrm{L} \mathrm{L}^{-1}$ LMnAc treatment for $24 \mathrm{~h}$ (Figure 9B), which indicated intracellular $\mathrm{Ca}^{2+}$ overload.

\subsection{LMnAc-induced intracellular ROS increase}

Mitochondria are the primary site of ROS generation within the cells and are also sensitive targets for ROS. To determine whether ROS were important in cell death induced by LMnAc, intracellular ROS levels were observed under a fluorescence microscope and measured by fluorescence spectrometry after being labeled with DCFH-DA. As shown

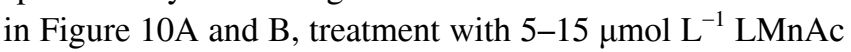
for $24 \mathrm{~h}$ led to an increase in ROS. ROS levels increased significantly with the detection of higher fluorescence intensities compared with the control group, and the level of increase was time-dependent (Figure 10C).

To confirm whether ROS were essential for LMnAcinduced cell death, cells were pretreated with NAC for $30 \mathrm{~min}$, 

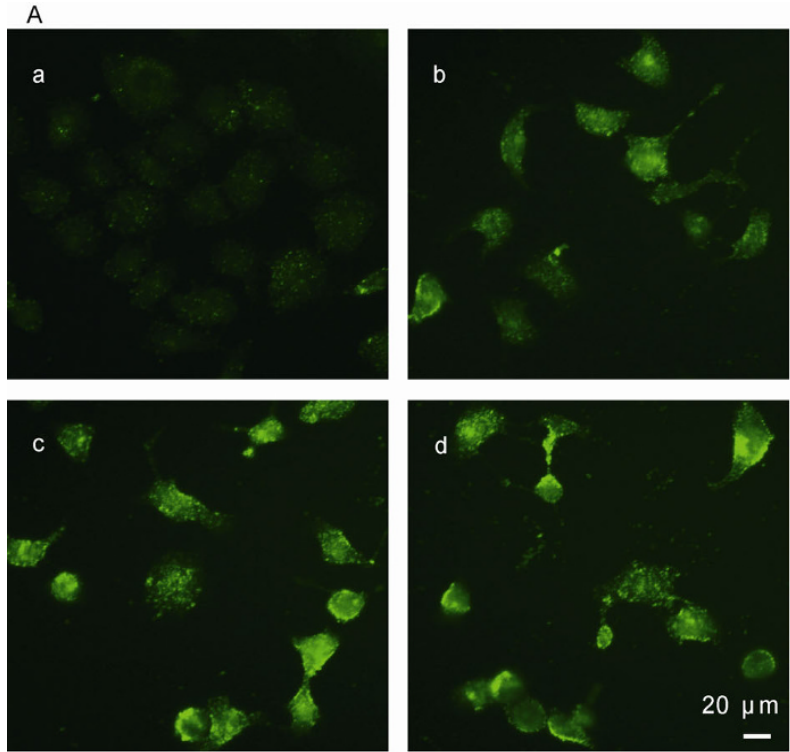

B

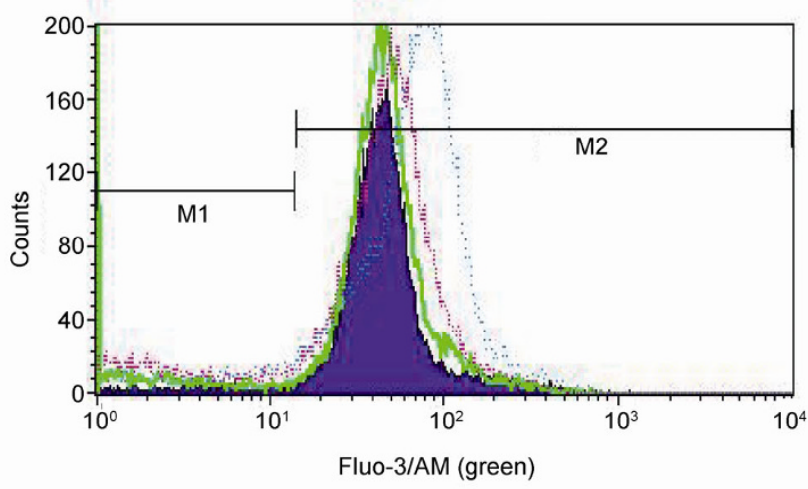

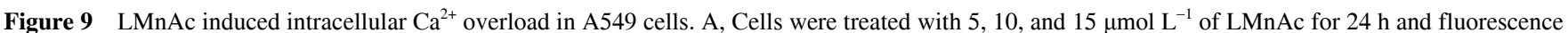
images were captured. a: control; b: $5 \mu \mathrm{mol} \mathrm{L}{ }^{-1}$; c: $10 \mu \mathrm{mol} \mathrm{L}{ }^{-1}$; d: $15 \mu \mathrm{mol} \mathrm{L}{ }^{-1}$. B, Intracellular $\mathrm{Ca}^{2+}$ levels were detected by FACS. Bluish violet peak: control; green peak: $6 \mathrm{~h}$; purple peak: $12 \mathrm{~h}$; blue peak: $24 \mathrm{~h}$.
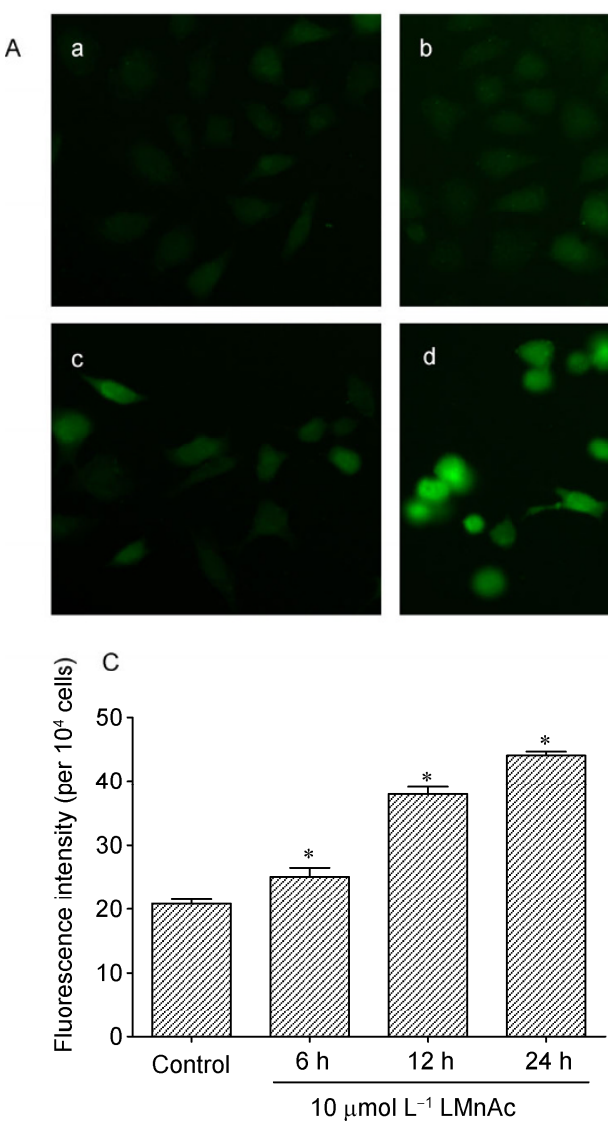
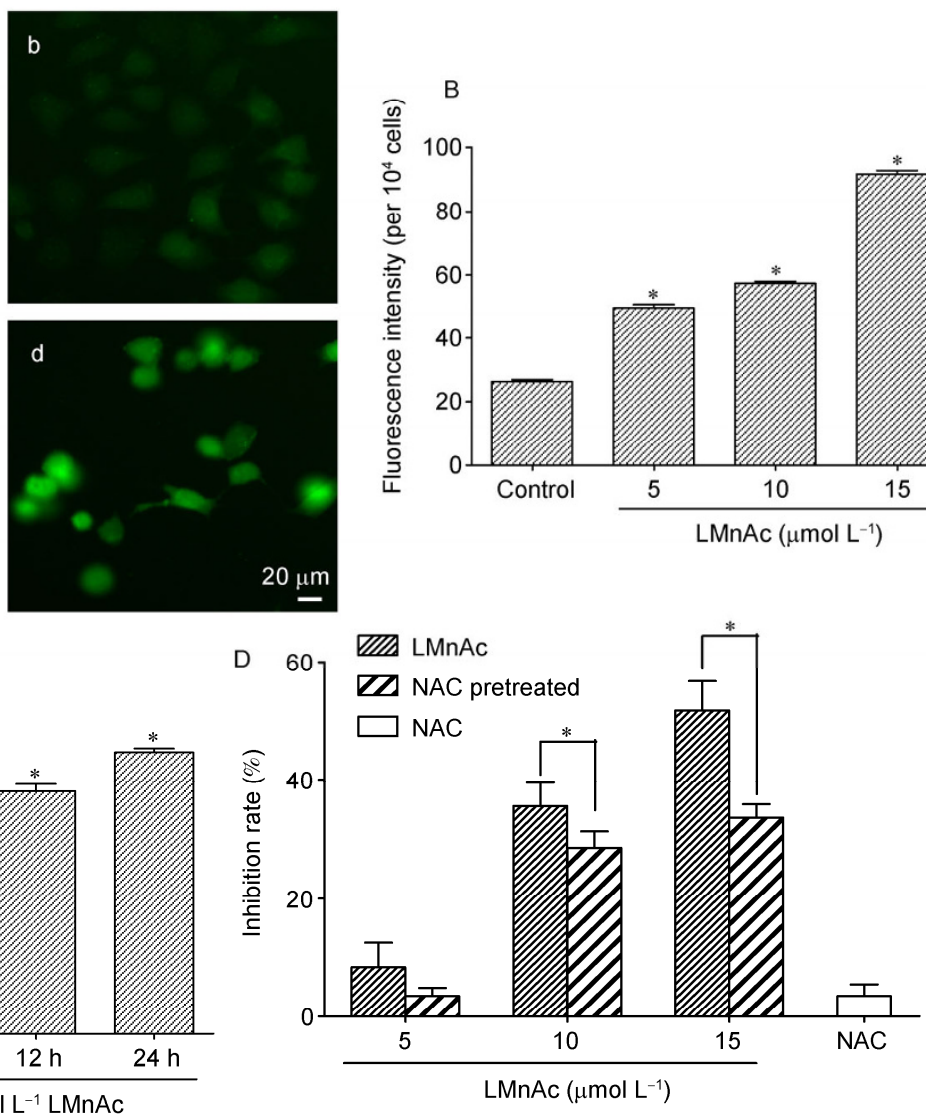

Figure 10 LMnAc triggered ROS generation in A549 cells. A, Cells were treated with 5, 10, and $15 \mu \mathrm{mol} \mathrm{L}{ }^{-1}$ of LMnAc for 24 h. Fluorescence images were captured. a: control; b: $5 \mu \mathrm{mol} \mathrm{L}{ }^{-1}$; : $10 \mu \mathrm{mol} \mathrm{L}{ }^{-1}$; d: $15 \mu \mathrm{mol} \mathrm{L}{ }^{-1}$. B, Fluorescence intensity was detected using the spectrophotofluorometer. C, Cells were treated with $10 \mu \mathrm{mol} \mathrm{L}{ }^{-1}$ of LMnAc for 6, 12, and $24 \mathrm{~h}$. Fluorescence intensity was detected using the spectrophotofluorometer. D, LMnAc-induced ROS increases were attenuated by NAC ( $\bar{x} \pm \mathrm{SD}, N=3,{ }^{*}, P<0.05$ vs. control). 
and then treated with LMnAc for $24 \mathrm{~h}$. The inhibition rate of LMnAc-treated cells was significantly decreased following pretreatment with NAC. This suggests that the toxicity of LMnAc was reduced by NAC (Figure 10D). These data demonstrate that LMnAc-mediated cell death may be related to its ability to elevate ROS levels.

\section{Discussion}

The potential of metal-based anticancer agents has not been fully investigated and realized until the successful application of cisplatin. Therefore, a series of manganesecompounds were synthesized to verify whether they could be used as anticancer drugs. From these studies, LMnAc was selected for further analysis.

In the present study, LMnAc showed activity against four human tumor cells of various origin. Further experiments indicated that LMnAc exhibited a dose- and time-dependent inhibition on A549 cells. Thus, LMnAc may be used as a potential candidate agent against cancer cells due to its selectivity. This compound exhibited superb selective and targeted characteristics against cancer cells over the popular chemotherapeutic reagent cisplatin. It is likely that LMnAc achieved its selectivity over cancer cells through specific binding and subsequent import via interaction between $\mathrm{Mn}$ (II) ions on the compound and divalent metal transporter (DMT-1) and TfR [8], which are highly expressed in some tumor tissues [42].

Most of the metal-complexes such as copper or cisplatin complexes have shown not only activity for DNA binding and cleavage, but also the ability to induce cell cycle arrest and apoptosis [12,43,44]. However, previous studies on LMnAc have shown moderate DNA binding [33]. In addition, manganese-complexes can induce apoptosis via the mitochondrial pathway in various cancer cells, which can induce mitochondrial membrane depolarization followed by Cyto $\mathrm{C}$ release to the cytoplasm and caspases $3 / 7$ activation [45]. In agreement with these studies, LMnAc was able to induce characteristics of apoptosis including nuclei condensation and apoptotic body emergence, which occurred through the mitochondrial pathway.

Meanwhile, it has been reported that autophagy plays a role in Mn nanoparticle-induced cell death [46]. The following characteristics of autophagy were also observed in the present study: formation of AVO and GFP-LC3 vacuoles, enhancement of lysosomal activity, increased expression of LC3 and Beclin-1, and conversion from LC3-I to LC3-II. It is interesting to note that autophagy seems to be the main mode of cell death following 5-10 $\mu \mathrm{mol} \mathrm{L}^{-1}$ LMnAc treatment for $24 \mathrm{~h}$ as 3-MA, an inhibitor of autophagy, could almost reduce cell death which was induced by $5-10 \mu \mathrm{mol} \mathrm{L}{ }^{-1} \mathrm{LMnAc}$, and partly reduce cell death following $15 \mu \mathrm{mol} \mathrm{L}{ }^{-1} \mathrm{LMnAc}$ treatment. Consistent with the data, autophagy occurred in the presence of polygonatum cyrtonema lectin, adriamycin and many other antitumor drugs at low concentrations. Interestingly, apoptosis also occurred, indicating apoptosis and autophagy could work together to induce cell death $[25,47]$. Therefore, this study strongly supports the fact that LMnAc induces both apoptotic and autophagic cell death.

It is well established that mitochondria play a central role in the process of cell death, including apoptosis and autophagy $[48,49]$. Recent findings convincingly point to mitochondria as a highly intriguing, thus far relatively valued anticancer target [32]. It has been proposed that mitochondria can regulate the release of proteins inducing apoptosis and autophagy through excessive ROS generation and self-directed induction of mitochondrial permeability transition (MPT) [32].

Moreover, mitochondria are the most important intracellular source of ROS, and it has been proposed that ROS could play regulatory roles in mediating cell death with mitochondrial dysfunction [50]. One common feature of cancer cells is the increase in ROS generation. Compelling evidence suggests that most cancer cells are under oxidative stress associated with increased metabolic activity and production of ROS. Excessive ROS accumulation will affect MMP and trigger a series of mitochondria-associated events, including MPTP opening, cytoplasmic $\mathrm{Ca}^{2+}$ accumulation, intracellular ATP level reduction, and MMP collapse [51], which would lead to loss of cell function, cell cycle arrest, apoptosis and autophagy [50,52-54]. Consistent with these observations, LMnAc could induce mitochondrial dysfunction, including MMP collapse, ATP depletion and intracellular free $\mathrm{Ca}^{2+}$ overload, after ROS accumulation. To confirm whether ROS is the main reason for cell death, NAC was used. The results showed that NAC, a ROS scavenger, significantly reduced LMnAc-induced cell death, which showed that ROS were involved and may be critical in LMnAc-induced cytotoxicity of A549 cells.

The reduced effects of anticancer drugs are becoming a major concern following long-term use of chemotherapy agents. This problem may be solved with the use of LMnAc because of its induction of both apoptosis and autophagic cell death, especially the latter. However, the interaction between apoptosis and autophagy following LMnAc treatment remains unclear and requires further research.

In summary, these findings indicate that the novel $\mathrm{Mn}$ compound LMnAc is a promising selective anticancer drug candidate. LMnAc exhibits potential and stable antiproliferative effects via inducing cell death triggered by ROS generation that is mediated through mitochondrial dysfunction.

This work was supported by the National Natural Science Foundation of China (21271090), the Natural Science Foundation of Jiangsu Province (BK2012710), the Society Developing Program of Zhenjiang (SH2008072), and the Senior Talent Start-up Fund of Jiangsu University (13JDG064). We thank Prof. Qin ZhengHong for providing GFP-LC3 expression vector and Prof. Li ChaoJun for $\mathrm{H}_{2} \mathrm{~B}-\mathrm{GFP}$ labeled HeLa cell line. 
1 Rosenberg B, Vancamp L. Platinum compounds: a new class of potent antitumour agents. Nature, 1969, 222: 385-386

2 Ott I, Gust R. Non platinum metal complexes as anti-cancer drugs. Arch Pharm (Weinheim), 2007, 340: 117-126

3 Köpf-Maier P. Antitumor activity of titanocene dichloride in xenografted human renal-cell carcinoma. Anticancer Res, 1999, 19: 493-504

4 Hartinger CG, Jakupec MA, Zorbas-Seifried S, Groessl M, Egger A, Berger W, Zorbas H, Dyson PJ, Keppler BK. KP1019, A new redox-active anticancer agent - preclinical development and results of a clinical phase I study in tumor patients. Chem Biodivers, 2008, 5: 2140-2155

5 Ansari KI, Grant JD, Kasiri S, Woldemariam G, Shrestha B, Mandal SS. Manganese(III)-salens induce tumor selective apoptosis in human cells. J Inorg Biochem, 2009, 103: 818-826

6 Rafique S, Idrees M, Nasim A, Akbar H, Athar A. Transition metal complexes as potential therapeutic agents. Biotech Mol Biol Rev, 2010, 5: 38-45

7 Wedler FC. Biological Significance of Manganese in Mammalian Systems. Prog Med Chem, 1993, 30: 89-133

8 El Mchichi B, Hadji A, Vazquez A, Leca G. p38 MAPK and MSK1 mediate caspase- 8 activation in manganese-induced mitochondria-dependent cell death. Cell Death Differ, 2007, 14: 1826-1836

9 Aschner M, Guilarte TR, Schneider JS, Zheng W. Manganese: recent advances in understanding its transport and neurotoxicity. Toxicol Appl Pharmacol, 2007, 221: 131-147

10 Zhou CY, Zhao J, Wu YB, Yin CX, Pin Y. Synthesis, characterization and studies on DNA-binding of a new $\mathrm{Cu}$ (II) complex with $N^{1}, N^{8}$-bis(1-methyl-4-nitropyrrole-2-carbonyl) triethylenetetramine. J Inorg Biochem, 2007, 101: 10-18

11 Hille A, Ott I, Kitanovic A, Kitanovic I, Alborzinia H, Lederer E, Wölfl S, Metzler-Nolte N, Schäfer S, Sheldrick WS, Bischof C, Schatzschneider U, Gust R. [N,N'-bis(salicylidene)-1,2-phenylenediamine] metal complexes with cell death promoting properties. J Biol Inorg Chem 2009; 14: 711-725

12 Kovala-Demertzi D, Hadjipavlou-Litina D, Staninska M, Primikiri A, Kotoglou C, Demertzis MA. Anti-oxidant, in vitro, in vivo anti-inflammatory activity and antiproliferative activity of mefenamic acid and its metal complexes with manganese(II), cobalt(II), nickel(II), copper(II) and zinc(II). J Enzyme Inhib Med Chem, 2009, 24: 742-752

13 Chen QY, Zhou DF, Huang J, Guo WJ, Gao J. Synthesis, anticancer activities, interaction with DNA and mitochondria of manganese complexes. J Inorg Biochem, 2010, 104: 1141-1147

14 Kondo Y, Kanzawa T, Sawaya R, Kondo S. Role of autophagy in cancer development and response to therapy. Nat Rev Cancer, 2005, 5: 726

15 Reed JC. Apoptosis-targeted therapies for cancer. Cancer Cell, 2003, 3: 17

16 Srdic-Rajic T, Zec M, Todorovic T, et al. Non-substituted Nheteroaromatic selenosemicarbazone metal complexes induce apoptosis in cancer cells via activation of mitochondrial pathway. Eur J Med Chem, 2011, 46: 3734-3747

17 Herr I, Debatin KM. Cellular stress response and apoptosis in cancer therapy. Blood, 2001, 98: 2603

18 Johnstone RW, Ruefli AA, Lowe SW. Apoptosis: a link between cancer genetics and chemotherapy. Cell, 2002, 108: 153-164

19 Galluzzi L, Maiuri MC, Vitale I, Zischka H, Castedo M, Zitvogel L, Kroemer G. Cell death modalities: classification and pathophysiological implications. Cell Death Differ, 2007, 14: 1237-1243

20 Rami A. Review: autophagy in neurodegeneration: firefighter and/or incendiarist? Neuropathol Appl Neurobiol, 2009, 35: 449-461

21 Chen S, Rehman SK, Zhang W, Wen A, Yao L, Zhang J. Autophagy is a therapeutic target in anticancer drug resistance. BBA-Rev Cancer, 2010, 1806: 220-229

22 Gozuacik D, Kimchi A. Autophagy as a cell death and tumor suppressor mechanism. Oncogene, 2004, 23: 2891-2906

23 Cheng Y, Qiu F, Tashiro S, Onodera S, Ikejima T. ERK and JNK mediate $\mathrm{TNF} \alpha$-induced $\mathrm{p} 53$ activation in apoptotic and autophagic L929 cell death. Biochem Biophys Res Commun, 2008, 376: 483-488

24 Moretti L, Yang ES, Kim KW, Lu B. Autophagy signaling in cancer and its potential as novel target to improve anticancer therapy. Drug Resist Update, 2007, 10: 135-143

25 Rubinsztein DC, Gestwicki JE, Murphy LO, Klionsky DJ. Potential therapeutic applications of autophagy. Nat Rev Drug Discov, 2007, 6: 304-312

26 Liu B, Cheng Y, Zhang B, Bian HJ, Bao JK. Polygonatum cyrtonema lectin induces apoptosis and autophagy in human melanoma A375 cells through a mitochondria-mediated ROS-p38-p53 pathway. Cancer Lett, 2009, 275: 54-60

27 Ghavami S, Eshragi M, Ande SR, Chazin WJ, Klonisch T, Halayko AJ, McNeill KD, Hashemi M, Kerkhoff C, Los M. S100A8/A9 induces autophagy and apoptosis via ROS-mediated cross-talk between mitochondria and lysosomes that involves BNIP3. Cell Res, 2009, 20: 314-331

28 Wei YH, Lee HC. Oxidative stress, mitochondrial DNA mutation, and impairment of antioxidant enzymes in aging. Exp Biol Med, 2002, 227: 671

29 Xu J, Dai X, Liu H, Guo WJ, Gao J, Wang CH, Li WB, Yao QZ. A novel 7-azaisoindigo derivative-induced cancer cell apoptosis and mitochondrial dysfunction mediated by oxidative stress. J Appl Toxicol, 2011, 31: 164-172

30 Zamzami N, Susin SA, Marchetti P, Hirsch T, Gomez-Monterrey I, Castedo M, Kroemer G. Mitochondrial control of nuclear apoptosis. J Exp Med, 1996, 183: 1533

31 Kuznetsov AV, Margreiter R, Amberger A, Saks V, Grimm M. Changes in mitochondrial redox state, membrane potential and calcium precede mitochondrial dysfunction in doxorubicin-induced cell death. Biochim Biophys Acta, 2011, 1813: 1144-1152

32 Gogvadze V, Orrenius S, Zhivotovsky B. Mitochondria as targets for cancer chemotherapy. Semin Cancer Biol, 2009, 19: 57-66

33 Zhou DF, Chen QY, Qi Y, Fu HJ, Li Z, Zhao KD, Gao J. Anticancer activity, attenuation on the absorption of calcium in mitochondria, and catalase activity for manganese complexes of $\mathrm{N}$-substituted di(picolyl)amine. Inorg Chem, 2011, 50: 6929-6937

34 Alley MC, Scudiero DA, Monks A, Hursey ML, Czerwinski MJ, Fine DL, Abbott BJ, Mayo JG, Shoemaker RH, Boyd MR. Feasibility of drug screening with panels of human tumor cell lines using a microculture tetrazolium assay. Cancer Res, 1988, 48: 589

35 Cohen GM, Sun XM, Snowden RT, Dinsdale D, Skilleter DN. Key morphological features of apoptosis may occur in the absence of internucleosomal DNA fragmentation. Biochem J, 1992, 286: 331

36 Biederbick A, Kern HF, Elsässer HP. Monodansylcadaverine (MDC) is a specific in vivo marker for autophagic vacuoles. Eur J Cell Biol, 1995, 66: 3

37 Smiley ST, Reers M, Mottola-Hartshorn C, Lin M, Chen A, Smith TW, Steele GD Jr, Chen LB. Intracellular heterogeneity in mitochondrial membrane potentials revealed by a J-aggregate-forming lipophilic cation JC-1. Proc Natl Acad Sci USA, 1991, 88: 3671

38 Lemasters JJ, Hackenbrock CR. Firefly luciferase assay for ATP production by mitochondria. Methods Enzymol, 1978, 57: 36-50

39 Takahashi A, Camacho P, Lechleiter JD, Herman B. Measurement of intracellular calcium. Physiol Rev, 1999, 79: 1089

40 Carter WO, Narayanan PK, Robinson JP. Intracellular hydrogen peroxide and superoxide anion detection in endothelial cells. J Leukoc Biol, 1994, 55: 253

41 Kabeya Y, Mizushima N, Ueno T, Yamamoto A, Kirisako T, Noda T, Kominami E, Ohsumi Y, Yoshimori T. LC3, a mammalian homologue of yeast Apg8p, is localized in autophagosome membranes after processing. EMBO J, 2000, 19: 5720-5728

42 Daniels TR, Delgado T, Helguera G, Penichet ML. The transferrin receptor part II: targeted delivery of therapeutic agents into cancer cells. Clin Immunol, 2006, 121: 159-176

43 Rajendiran V, Karthik R, Palaniandavar M, Stoeckli-Evans H, Periasamy VS, Akbarsha MA, Srinag BS, Krishnamurthy H. Mixed- 
ligand copper(II)-phenolate complexes: effect of coligand on enhanced DNA and protein binding, DNA cleavage, and anticancer activity. Inorg Chem, 2007, 46: 8208-8221

44 Shi ZY, Li YQ, Kang YH, Hu GQ, Huang-fu CS, Deng JB, Liu B. Piperonal ciprofloxacin hydrazone induces growth arrest and apoptosis of human hepatocarcinoma SMMC-7721 cells. Acta Pharmacol Sin, 2012, 33: 271-278

45 Shibata S, Maeda M, Furuta K, Suzuki M, Oh-Hashi K, Kiuchi K, Hirata Y. Neuroprotective effects of (arylthio)cyclopentenone derivatives on manganese-induced apoptosis in PC12 cells. Brain Res, 2009, 1294: 218-225

46 Afeseh Ngwa H, Kanthasamy A, Gu Y, Fang N, Anantharam V, Kanthasamy AG. Manganese nanoparticle activates mitochondrial dependent apoptotic signaling and autophagy in dopaminergic neuronal cells. Toxicol Appl Pharmacol, 2011, 256: 227-240

47 Di X, Shiu RP, Newsham IF, Gewirtz DA. Apoptosis, autophagy, accelerated senescence and reactive oxygen in the response of human breast tumor cells to Adriamycin. Biochem Pharmacol, 2009, 77: $1139-1150$

48 Grandemange S, Herzig S, Martinou JC. Mitochondrial dynamics and cancer. Semin Cancer Biol, 2009, 19: 50-56

49 Goldman SJ, Taylor R, Zhang Y, Jin S. Autophagy and the degradation of mitochondria. Mitochondrion, 2010, 10: 309-315

50 Guo WJ, Ye SS, Cao N, Huang J, Gao J, Chen QY. ROS-mediated autophagy was involved in cancer cell death induced by novel copper(II) complex. Exp Toxicol Pathol, 2010, 62: 577-582

51 Hausenloy DJ, Ong SB, Yellon DM. The mitochondrial permeability transition pore as a target for preconditioning and postconditioning. Basic Res Cardiol, 2009, 104: 189-202

52 Franke JC, PlÖtz M, Prokop A, Geilen CC, Schmalz HG, Eberle J. New caspase-independent but ROS-dependent apoptosis pathways are targeted in melanoma cells by an iron-containing cytosine analogue. Biochem Pharmacol, 2010, 79: 575-586

53 Scherz-Shouval R, Shvets E, Fass E, Shorer H, Gil L, Elazar Z. Reactive oxygen species are essential for autophagy and specifically regulate the activity of Atg4. EMBO J, 2007, 26: 1749-1760

54 Li J, Xu Z, Tan M, Su W, Gong XG. 3-(4-(Benzo[d]thiazol-2yl)-1-phenyl-1H-pyrazol-3-yl) phenyl acetate induced Hep G2 cell apoptosis through a ROS-mediated pathway. Chem Biol Interact, 2010, 183: 341-348

Open Access This article is distributed under the terms of the Creative Commons Attribution License which permits any use, distribution, and reproduction in any medium, provided the original author(s) and source are credited. 